\title{
The incidence of anti-ATLA (antibodies to adult $T$ -cell leukemia-associated antigen) among hemodialysis patients in the Kagoshima district with special reference to blood transfusion
}

\author{
Toshiaki Uematsu, M. D., Shuichi Hanada, M. D., Koichiro Nomura, M. D. *, Kazuya Osaki, M. D., \\ Etsuo Yoshidome, M. D., Shinichiro Uemura, M. D., Ryuji Harada, M. D., Ýoshihito Ostuji, M. D., \\ and Shuji Hashimoto, M. D. \\ The 2nd Department of Internal Medicine, Faculty of Medicine, Kagoshima University ; Internal \\ Medicine, Hokusatsu Prefectural Hospital*
}

(昭和 60 年 11 月 22 日受付)

key words : hemodialysis patients, ATL, HTLV-1, anti-ATLA, blood transfusion 〈abstract〉

The incidence of anti-ATLA was investigated in 234 patients with chronic renal failure under hemodialysis. The results obtained were as follows. 1) The seropositivity of the patients $(33.8 \%)$ was higher than that of healthy residents (11.7\%) and blood donors (6.9\%) in the Kagoshima district, an ATL-endemic area $(p<0.01) .2)$ There was no correlation between the duration of hemodialysis and anti-ATLA positivity. 3 ) The incidence of anti -ATLA increased with the rise in the number of blood transfusions given $(p<0.05) .4)$ The seropositivity of patients without episodes of blood transfusion was also higher than that of healthy residents in the Kagoshima district $(p<0.05)$. The data suggested that HTLV-1 was transmissible by blood transfuion, and that therefore it seems necessary to carry out mass-screening of blood units to prevent the spread of HTLV-1 infection in ATL -endemic areas, as soon as possible. Further future studies to clarify why the seropositivity of patients without blood transfusion was statistically high may also be necessary.

\section{鹿児島県血液透析患者における抗 ATLA 抗体の検索 一特に輸血との関連について一}

植松 俊昭 花田 修一 野村紘一郎* 大崎 和弥 上村伸一郎 原田 隆二 尾辻 義人 橋本 修治 鹿児島大学第 2 内科 鹿児島県立北薩病院内科*

輸血を受ける機会の多い血液透析中の慢性腎不全患者 234 例について, 血清抗 ATLA 抗体を測定, HTLV- I 感染と 輸血との関連について検討し，以下の結果を得た。1) 鹿児島県下の血液透析患者の抗 ATLA 抗体陽性率は $33.8 \%$, 鹿児島県一般健常人の陽性率 $11.7 \%$ より高率であった $(\mathrm{p}<0.01)$ ．2）血液透析患者における抗 ATLA 抗体陽性率 は，鹿児島県一般健常人にみられる加齢に伴う増加を示さなかった。3）血液透析患者における抗ATLA 抗体陽性率 と透析期間との間には, 有意の相関は認めなかった。 4 ）輸血の有無と抗 ATLA 抗体陽性率（輸血のある群の陽性率 $37.7 \%$, 輸血のない群の陽性率 $25.0 \%$ ) との間には, 統計学的有意差は認め難かったものの, 輸血回数の増加に伴い, 抗 ATLA 抗体陽性率は有意に $(p<0.05)$ 増加した。 5$)$ 輸血歴のない群での抗 ATLA 抗体陽性率も, 鹿児島県一 般健常人に比べ有意に $(P<0.01)$ 高く, 輸血以外の因子の存在も示唆された.

今回の検討では, 輸血歴のない患者群での抗 ATLA 抗体陽性率が, 鹿児島県一般健常人に比し, なぜ高いのか明ら かにできなかった，今回の検討から輸血の回数が増加するに伴い，抗 ATLA 抗体陽性率の上昇が明らかになった。こ

植松 俊昭 鹿児島大学医学部第 2 内科

₹ 890 鹿児島市宇宿町 1208-1（0992-64-2211） 
の事から HTLV- I の輸血による感染が示唆され, 特に鹿児島県地方などの HTLV- I 浸淫地では, HTLV- I の輸血に よる感染を防ぐため早急の対策が必要と思われた。

\section{Introduction}

Adult T-cell leukemia (ATL) is a new clinical entity, initially proposed by Takatsuki and his colleagues $^{1}$. ATL presents some characteristic clinical and hematological features, and a specific geographical distribution as follows ; (1) onset in adulthood ; (2) subacute or chronic leukemia with rapidly progressive terminal course ; (3) resistance to treatment with current antileukemic agents ; (4) leukemic cells are pleomorphic in appearance with deeply indented or lobulated nuclei morphologically, and have peripheral $\mathrm{T}$-cell surface markers; (5) frequent accompaniment of lymphadenopathy, hepatosplenomegaly, skin lesions, pulmonary lesions and hypercalcemia ; (6) absence of mediastinal tumor ; (7) the birthplaces of patients are clustered in restricted areas of southwestern Japan, including the Kagoshima district $^{2 \sim 4)}$.

A human type-C retrovirus, designated ATL virus (ATLV)/human T-cell leukemia virus type 1 (HTLV - I ) has been revealed to be closely related to outbreaks of ATL, etiologically ${ }^{5,6)}$. That is, antibodies to ATL-associated antigen (ATLA), abbreviated as anti -ATLA, have been detected in the sera of almost all patients with ATL. Furthermore, the incidence of seropositivity has been found to be high in healthy residents in ATL-endemic areas, including members of patients families, but to be very low in healthy residents in non-endemic areas ${ }^{4,7}$. HTLV-1 is known to be more transmissible by cell-to-cell rather than free virus-to-cell contact at the tissue culture level ${ }^{8,9)}$. On the other hand, a subject having anti-ATLA is currenthy considered to be an HTLV-1 carrier ${ }^{10 \sim 12)}$. Besides, Okochi et $\mathrm{al}^{13)}$., Shimoyama et $\mathrm{al}^{14)}$., Hino et $\mathrm{a}^{15)}$., and Fujishita ${ }^{16)}$ and Momita ${ }^{17)}$ have reported evidence of seroconversion of blood recipients and have suggested that infection of HTLV-1 occurs via transfused blood cells rather than the plasma component. From these facts, blood, especially cell component transfusion, has become a great problem in ATL -endemic areas, such as the Kagoshima district.

In order to clarify the effect of blood transfusions on the spread of HTLV-1 in the Kaghoshima district, we studied the sera of patients with chronic renal failure $(\mathrm{CRF})$ under hemodialysis, who are more likely to receive massive blood transfusion, for the presence of anti-ATLA.

\section{Materials and methods}

Patients with CRF under hemodialysis: Of 234 patients either ambulatory or hospitalized in our related hospitals, Kagoshima district, 115 were male and 119 were female, with an average age of $49.3 \pm 14$. 0 (range 21 to 77) years. Almost all of the patients were born and had lived in the Kagoshima district since the early period of their lives. The seropositivity of the anti-ATLA of the patients was studied in relation to sex, age, duration of hemodialysis and the number of times they had received blood transfusion, in comparison with healthy residents in the Kagoshima district (previously reported) ${ }^{18)}$.

Immunoassay for anti-ATLA: The method of determining antibodies in this study was by enzyme -linked-immunosorbent assay (ELISA). The assay kit (E-0733) was kindly supplied by Eisai. Co., Tokyo. The procedures were as follows. One hundred microliters of normal rabbit serum (NRS) containing 20 mM EDTA buffered to $\mathrm{pH} 8.0$ with $0.05 \mathrm{M}$ Tris-HCL was added to the wells, and coated with ATLA extracted from MT-2 cells which produce large amounts of HTLV -1 . Then the test sera $(20 \mu l)$ were added at $2^{\circ} \mathrm{C}$. One hundred and twenty microliters of NRS was added to the wells as a blank. For the first reaction, the wells were incubated at $40^{\circ} \mathrm{C}$ for $30 \mathrm{~min}$, and then cooled rapidly to $2^{\circ} \mathrm{C}$. After 3 washes with saline, for the second reaction, $100 \mu l$ of alkaline phosphatase-labeled anti-human IgG rabbit serum was added to the wells. After incubation at $40^{\circ} \mathrm{C}$ for 30 min, the wells were cooled to $2^{\circ} \mathrm{C}$ and washed 3 times with saline. The final enzyme reaction was carried out by adding $100 \mu l$ of $\mathrm{p}$-nitrophenyl phosphate solution and incubating the mixture at $40^{\circ} \mathrm{C}$ for $30 \mathrm{~min}$. The reaction was stopped by adding $100 \mu l$ of $4 \% \mathrm{NaOH}$ after cooling to $2^{\circ} \mathrm{C}$. The absorbance at $405 \mathrm{~nm}$ was employed using a spectrophotometer (UVIDEC-40, Nihon Bunko Medical). The cut-off value was determined as the optical density rate of the blank plus 0.05 . 
Sera showing an optical density of 0.30 or higher were taken as positive for anti-ATLA. Moreover, in order to exclude non-specific reactions due to non-ATLA factors, an inhibition test was carried out for those sera showing an optical density from the cut-off value to 0.30 . After the test sera $(20 \mu l)$ had been added to the non-coated wells of ATLA, NRS $(100 \mu l)$ as a control and ATLA solution $(100 \mu l)$ for inhibition were added to each well. After incubation at $37^{\circ} \mathrm{C}$ for $60 \mathrm{~min}$, the wells were cooled to $2^{\circ} \mathrm{C}$, and the sera of the wells were then transferred to the ATLA-coated wells and the reaction was carried out by the the same procedures as those mentioned above. Sera showing an inhibition of above $50 \%$ were regared as being seropositive.

\section{Results}

1. The incidence of anti-ATLA in patients with $\mathrm{CRF}$ under hemodialysis

Thirty-two out of 115 males (27.8\%), 47 out of 119 females $(39.5 \%)$ and 79 out of the total of $234(33.8 \%)$ were found to be seropositive. The anti-ATLA ser-

\begin{tabular}{|c|c|c|}
\hline & $\begin{array}{c}\text { positive cases } \\
\text { of anti-ATLA }\end{array}$ & $\begin{array}{c}\text { anti-ATLA positivity } \\
(\%)\end{array}$ \\
\hline $\begin{array}{l}\text { hemodialysis } \\
\text { patients (male) }\end{array}$ & 32 & $\begin{array}{c}27.8 \\
(32 \text { cases } / 115 \text { cases })\end{array}$ \\
\hline $\begin{array}{l}\text { hemodialysis } \\
\text { patients (female) }\end{array}$ & 47 & $\begin{array}{c}39.5 \\
(47 / 119)\end{array}$ \\
\hline total & 79 & $\begin{array}{c}33.8 \\
(79 / 234)\end{array}$ \\
\hline $\begin{array}{l}\text { healthy residents } \\
\text { (Kagoshima district) } \\
16 \mathrm{y} \sim 86 \mathrm{y}\end{array}$ & 297 & $\begin{array}{c}11.7 \\
(297 / 2,533)\end{array}$ \\
\hline $\begin{array}{l}\text { blood donors } \\
\text { (Kagoshima district) } \\
\qquad 16 \mathrm{y} \sim 64 \mathrm{y}\end{array}$ & 41 & $\begin{array}{c}6.9 \\
(41 / 596)\end{array}$ \\
\hline
\end{tabular}

Table 1 The incidence of anti-ATLA in patients with CRF under hemodialysis opositivity of the patients was statistically higher than that of normal residents (297 out of 2,533, 11.7\%) and blood donors (41 out of 596, 6.9\%) in the Kagoshima district $(\mathrm{p}<0.01)^{18)}$. The anti-ATLA reactivity in females was higher than that in males, but no statistical difference was recognized between the sexes (Table 1).

2. Correlation between the age of the patients and anti-ATLA positivity

The patients were divided into 6 groups according to each ten-years age period. The positive rate of anti -ATLA increased with age in the normal healthy residents in Kagoshima, while it did not increase in the natients. Comparing the seropositivity of the patients with that of normal healthy residents in the Kagoshima district, the former was statistically higher in every age group $(\mathrm{p}<0.01)$ (Table 2$)$.

3 . Correlation between the duration of hemodialysis and anti-ATLA positivity

The patients were divided into four groups according to the duration of hemodialysis, namely, Group I ; less than one year (35 cases), Group 2; from one year to less than 5 years (134 cases), Group 3 ; from 5 years to less than 10 years ( 52 cases), and Group 4 ; from 10 years to 13 years (11 cases). The seropositivity in each of the groups was $28.6 \%$ (10 out of 35 ), $34.3 \%$ (46 out of 134 ), 34.6\% (18 out of 52 ) and 45 . $5 \%$ (5 out of 11), respectively (Table 3 ).

4. Correlation between episodes of blood transfusion and the incidence of anti-ATLA

The blood units transfused were mainly whole blood (fresh or stored) and packed red cells supplied by Kagoshima Red Cross Blood Center. The positive rate of anti-ATLA was $37.7 \%$ (61 out of 162) in group A with episodes of blood transfusion and $25.0 \%$ (18 out of 72) in group B without episodes of blood transfu-

\begin{tabular}{l|c|c|c|c|c|c}
\hline & $21 \sim 30 \mathrm{y}$ & $31 \sim 40 \mathrm{y}$ & $41 \sim 50 \mathrm{y}$ & $51 \sim 60 \mathrm{y}$ & $61 \sim 70 \mathrm{y}$ & $71 \sim 79 \mathrm{y}$ \\
\hline $\begin{array}{l}\text { positive cases of } \\
\text { anti-ATLA }\end{array}$ & 6 & 18 & 13 & 18 & 16 & 8 \\
\hline $\begin{array}{l}\text { anti-ATLA } \\
\text { positivity (\%) }\end{array}$ & $\begin{array}{c}28.5 \\
(6 / 21 \text { cases) }\end{array}$ & $\begin{array}{c}31.6 \\
(18 / 57)\end{array}$ & $\begin{array}{c}28.3 \\
(13 / 46)\end{array}$ & $\begin{array}{c}37.5 \\
(18 / 48)\end{array}$ & $\begin{array}{c}33.3 \\
(16 / 48)\end{array}$ & $\begin{array}{c}57.1 \\
(8 / 14)\end{array}$ \\
\hline $\begin{array}{l}\text { anti-ATLA positivity } \\
\begin{array}{l}\text { of healthy residents } \\
\text { (Kagoshima district) (\%) }\end{array}\end{array}$ & $\begin{array}{c}6.5 \\
(21 / 321)\end{array}$ & $\begin{array}{c}8.1 \\
(26 / 320)\end{array}$ & $\begin{array}{c}11.4 \\
(63 / 553)\end{array}$ & $\begin{array}{c}12.9 \\
(84 / 649)\end{array}$ & $\begin{array}{c}17.5 \\
(65 / 371)\end{array}$ & $\begin{array}{c}25.2 \\
(29 / 115)\end{array}$ \\
\hline
\end{tabular}

Table 2 Correlation between the age of hemodialysis patients and anti-ATLA positivity 
sion. The positive rate of anti-ATLA in both the two groups was higher than that in the healthy residents in the Kagoshima district $(p<0.01)$. No statistical differences between group A and group B were found with regard to the incidence of anti-ATLA (Table 4).

5 . Correlation between the number of blood transfusions received and anti-ATLA positivity

The patients were divided into 3 groups, the first group without blood transfusions (72 cases), the second group with from 1 to 10 blood transfusions (140

\begin{tabular}{l|c|c}
\hline $\begin{array}{c}\text { duration of } \\
\text { hemodialysis }\end{array}$ & $\begin{array}{c}\text { positive cases } \\
\text { of anti-ATLA }\end{array}$ & $\begin{array}{c}\text { anti-A TLA positivity } \\
\text { (\%) }\end{array}$ \\
\hline less than 1 year & 10 & $28.6(10 / 35$ cases $)$ \\
\hline $\begin{array}{l}\text { more than 1 year } \\
\text { but less than 5 }\end{array}$ & 46 & $34.3(46 / 134)$ \\
\hline $\begin{array}{l}\text { more than 5 years } \\
\text { but less than 10 }\end{array}$ & 18 & $34.6(18 / 52)$ \\
\hline from 10 to 13 years & 5 & $45.5(5 / 11)$ \\
\hline total & 79 & $33.8(79 / 234)$ \\
\hline
\end{tabular}

Table 3 Correlation between the duration of hemodialysis and anti-ATLA positivity

\begin{tabular}{c|c|c}
\hline $\begin{array}{r}\text { episodes of blood } \\
\text { transfusion }\end{array}$ & $\begin{array}{r}\text { positive cases of } \\
\text { anti-ATLA }\end{array}$ & $\begin{array}{c}\text { anti-ATLA positivity } \\
(\%)\end{array}$ \\
\hline$(+)$ & 61 & $37.7(61 / 162$ cases $)$ \\
$(-)$ & 18 & $25.0(18 / 72)$ \\
\hline total & 79 & $33.8(79 / 234)$ \\
\hline
\end{tabular}

Table 4 Correlation between episodes of blood transfusion and anti-ATLA positivity

\begin{tabular}{c|c|c}
\hline $\begin{array}{c}\text { number of blood } \\
\text { transfusions }\end{array}$ & $\begin{array}{c}\text { anti-ATLA } \\
\text { positive cases }\end{array}$ & $\begin{array}{c}\text { anti-ATLA positivity } \\
(\%)\end{array}$ \\
\hline 0 & 18 & $25.0(18 / 72$ cases $)$ \\
$1 \sim 10$ & 48 & $34.3(48 / 140)$ \\
$11 \sim 79$ & 13 & $59.1(13 / 22)$ \\
\hline total & 79 & $33.8(79 / 234)$ \\
\hline
\end{tabular}

Table 5 Correlation between the number of blood transfusions and anti-ATLA positivity cases) and the third group with from 11 to 79 transfusions (22 cases). The seropositivity of each group was $25.0 \%$ (18 out of 72 ), $34.3 \%$ ( 48 out of 140 ) and $59.1 \%$ (13 out of 22), respectively. No differences in anti -ATLA positivity were seen between the group with blood transfuion and the group without blood transfuion, as mentioned above. However, the incidence of anti-ATLA increased with the number of blood transfusions given $(\mathrm{p}<0.05)$ (Table 5$)$.

6 . Correlation between anti-ATLA positivity, age and the episodes of blood transfusion

In patients without any episode of blood transfusion, the seropositivity was similar in each of the age groups and was not increased with age except for a small number of patients over 71 years old. The same findings were also seen in patients with episodes of blood transfusion (Table 6).

\section{Discussion}

From this study of 234 patients with CRF under hemodialysis, anti-ATLA was detected by ELISA in 32 out of $115(27.8 \%)$ males, 47 out of $119(39.5 \%)$ females and 79 out of a total of $234(33.8 \%)$. The seropositivity of the patients was statistically higher than that of the normal residents in the Kagoshima district (297 out of $2,533,11.7 \%)^{18)}$. Sixty-one out of 79 patients with anti-ATLA had had episodes of blood transfusion. The incidence of anti-ATLA in patients with blood transfusion increased with the number of blood transfusions given. The results of our study thus suggested the possibility of transmission of HTLV-1 by blood transfusion, as others have reported ${ }^{13 \sim 17)}$.

Interestingly, the seropositivity of patients without blood transfusion (18 cases) was also higher than that of healthy residents in the Kagoshima district. Possible explanations for the increased appearance of the antibody in these patients are as follows: (1) some relation between HTLV-1 and the outbreak of renal failure, (2) chance clustering of HTLV-1 in these

\begin{tabular}{l|c|c|c|c|c|c|c}
\hline & $21 \sim 30 \mathrm{y}$ & $31 \sim 40 \mathrm{y}$ & $41 \sim 50 \mathrm{y}$ & $51 \sim 60 \mathrm{y}$ & $61 \sim 70 \mathrm{y}$ & $71 \sim 79 \mathrm{y}$ & total \\
\hline $\begin{array}{l}\text { without blood } \\
\text { transfusion }\end{array}$ & $25.0 \%$ & 15.4 & 25.0 & 20.0 & 29.4 & 42.9 & 25.0 \\
\hline with blood & $2 / 8$ cases $)$ & $(2 / 13)$ & $(3 / 12)$ & $(3 / 15)$ & $(5 / 17)$ & $(3 / 7)$ & $(18 / 72)$ \\
transfusion & $30.8 \%$ & 36.4 & 29.4 & 45.5 & 35.5 & 71.4 & 37.7 \\
\hline $\begin{array}{l}\text { healthy residents } \\
\text { (Kagoshima district) }\end{array}$ & $\begin{array}{c}(2 / 13 \text { cases }) \\
(21 / 321 \text { persons })\end{array}$ & $(16 / 44)$ & $(10 / 34)$ & $(15 / 33)$ & $(11 / 31)$ & $(5 / 7)$ & $(61 / 162)$ \\
\hline
\end{tabular}

Table 6 Correlation between anti-ATLA positivity, age and episodes of blood transfusion 
patients families, (3) increased production of anti -ATLA in these patients, (4) transmission of HTLV-1 from medical or paramedical co-workers in hemodialysis units, (5) transmission of HTLV-1 due to the techniques used in hemodialysis. The first possibility is unlikely, since patients with CRF are not especially clustered in ATL-endemic areas. However, some renal diseases are caused by immune mechanisms, such as the depostiion of immune complexes in renal glomeruli ${ }^{19,20)}$. It might therefore be important to study the correlation between ATLA-anti-ATLA complexes and renal failure. The second possibility is also unlikely but canot be completely excluded, since HTLV -1 is frequently clustered in the family of the seropositive person ${ }^{12,18,21,22)}$. It is suggested that the transmission of HTLV-1 can occur from mother to child transplacentally or in early infancy, and also between spouses, especially from husband to wife $^{12,18,21,22)}$. The third possibility also seens unlikely, since the production of anti-HBs antibody has been reported to be decreased in hemodialysis patients after $\mathrm{HBs}$ antigen vaccination ${ }^{23,24)}$. The fourth possibility is also unlikely, as the anti-ATLA reactivity of hemodialysis co-workers in our hospitals was similar to that of healthy residents in the Kagoshima district (unpublished data). The fifth possibility was further unlikely, since the dialysers used in our hospitals are disposed of and anti-ATLA reactivity was revealed to be unrelated to the duration of hemodialysis in this study.

Consequently, it appears to be conclusive that HTLV-1 is transmissible by blood transfusion, so that blood transfusion must be considered to be an important pathway of HTLV-1 infection. In this study, we were unable to clarify the reason why the anti-ATLA of patients without blood transfusion was statistically higher than that of the healthy residents in Kagohima ${ }^{18)}$. In this repect, a further study may be necessary in future. As it is suspected that there are many blood units harboring HTLV-1 in Kagoshima ${ }^{18)}$, the number of carrieres of the virus may be increased through the use of blood transfusion and these individuals in turn could be come sources of further infection. Although no outbreak of ATL has yet been linked to blood transfusion, it seems necessary to carry out mass-screening of blood units as soon as possible to prevent the expansion of HTLV-1 infection in ATL -endemic areas such as the Kagoshima district.

\section{References}

1) Takatsuki, K., Uchiyama, T., Sagawa, K. \& Yodoi, J.: Adult T-cell leukemia in Japan. S. Seno, F. Takaku \& S. Irino (ed.), Topics in hematology, p. 73-77, Excepta Medica, Amsterdam, 1977.

2) Uchiyama, T., Yodoi, J., Sagawa, K., Takatsuki, K. \& Uchino, H. : Adult T-cell leukemia : Clinical and hematologic features of 16 cases. Blood, 50 : 481-492, 1977.

3) The T-and B-cell maliganancy study group: Statistical analysis of immunologic, clinical and histopathologic data on lymphoid malignancies in Japan., Jpn. J. Clin. Onco., 11(1) : 15-37, 1981.

4) Yunoki, K., Matsumoto, M., Matsumoto, T., Kikuchi, H., Nomura, K., Furusho, H., Nishioka, K. \& Hanada, S.: Adult $T$ cell leukemia in Kagoshima: its clinical features and skin lesions. GANN Monograph on Cancer Research, 28:151 $-165,1982$.

5) Yoshida, M., Miyoshi, I. \& Hinuma, Y. : Isolation and characterization of retrovirus from cell lines of human adult $\mathrm{T}$-cell leukemia and its implication in the diseases. Pro. Natl. Acad. Sci. U. S. A., 79 : 2031-2035, 1982.

6) Poiez, B. J., Ruscetti, F. W., Gazdar, A. F., Bunn, P. A., Minna, J. D. \& Gallo R. C. : Detection and isolation of type $\mathrm{C}$ retrovirus particles from fresh and cultured lymphocytes of a patient with cutaneous T-cell lymphoma. Proc. Natl. Acad. Sci. U.S. A., $77:$ 7415-7419, 1980.

7) Hinuma, Y., Nagata, K., Hanaoka, M., Nakai, M., Matsumoto, T., Kinoshita, K., Shirakawa, S. \& Miyoshi, I. : Adult T-cell leukemia: Antigen in an ATL cell line and detection of antibodies to the antigen in human sera. Proc. Natl. Acad. Sci. U. S. A., $78: 6476-6480,1981$.

8) Chosa, T., Yamamoto, N., Tanaka, Y., Koyanagi, Y. \& Hinuma, Y. : Infectivity dissociated from transforming activity in a human retrovirus, adult T-cell leukemia virus. Gann, 73 : 844-847, 1982.

9) Miyoshi, I., Yoshimoto S., Kubonishi, I., Taguchi, H., Shiraish, Y., Ohtuski, Y. \& Akagi, T. : Trans- 
formation of normal human cord lymphocytes by co-cultivation with a lethally irradiated human $\mathrm{T}$ -cell line carrying type $\mathrm{C}$ virus particles. Gann, 72 : 997-998, 1981.

10) Miyoshi, I., Fujishita, M., Taguchi, H., Ohtsuki, Y., Akagi, T., Morimoto, Y. \& Nagasaki., A. : Caution against blood transfusion from donors positive to adult T-cell leukemia-associated antigens. Lancet, 20 : 683-684, 1982.

11) Gotoh, Y., Sugamura, K. \& Hinuma, Y. : Healthy carriers of a human retrovirus, adult $\mathrm{T}$-cell leukemia virus (ATLV): Demonstration by clonal culture of ATLV-carrying T cell from peripheral blood. Proc. Natl. Acad. Sci. U.S. A., $79: 4780$ -4782, 1982.

12) Miyoshi, I., Taguchi, H., Fujishita, M., Niiya, K., Kitagawa, T., Ohtsuki, Y. \& Akagi, T. : Asymptomatic type $\mathrm{C}$ virus carriers in the family of an adult T-cell leukemia patient. Gann, 73 : 339-340, 1982.

13) Okochi, K., Sato, H. \& Hinuma, Y. : A retrospective study on transmission of adult $\mathrm{T}$ cell leukemia virus by blood transfusion: Seroconversion in recipients. Vox Sang, $46:$ 245-253, 1984.

14) Shimoyama, M., Minato, K., Tobinai, K., Horikoshi, N., Ibuka, T., Deura, K., Nagatani, T., Ozaki, Y., Inada, N., Komoda, H. \& Hinuma, Y. : Anti -ATLA (antibody to the adult T-cell leukemia cell-associated antigen)-positive hematologic malignancies in the Kanto district. Jpn. J. Clin. Onco., 12 : 109-116, 1982.

15) Hino, S., Kawamichi, T., Funakoshi, M., Kanamura, M., Kitamura, T. \& Miyamoto, T. : Transfusion mediated spread of the human T-cell leukemia virus in chronic hemodialysis patients in a heavily endemic area, Nagasaki. Gann, $75: 1070$ $-1075,1984$.

16) Fujishita, M. : Studies of adult T-cell leukemia Part I Detection of anti-ATLA antibody in patients with various conditions and healthy controls with special reference to blood transfusion. Japan J. Clin. Hemat., $24: 111-118$, 1983. (in
Japanese)

17) Momita, S. : Detection of anti-ATLA (adult T cell leukemia associated antigen) antibody in Nagasaki district, ATL-endemic area. J. Jap. Soc. Intern. Med., $73: 309-315$, 1984. (in Japanese)

18) Nomura, K. : A study of anti-ATLA (antibodies to adult $\mathrm{T}$-cell leukemia virus associated antigens) in healthy subjects-A sero -epidemiological study on residents of Kagoshima prefecture and a family study of patients with adult $\mathrm{T}$-cell leukemia-lymphoma and other diseases-. IGAKU KENKYU (ACTA MEDICA), $54: 750-781,1984$. (in Japanese)

19) Abass, C. K., Hall, C. L., Border, W, A., Brown, C. A., Glassock, R. J., Coggins, C. H., \&. the collaborative study of the adult idiopathic nephrotic syndrome. : Circulating immune complexes in adult with idiopathic nephrotic syndrome. Kidney int., $17: 545-553,1980$.

20) Border, W. A. : Immune complex detection in glomerular disease. Nephron, 24 : 105-113, 1979.

21) Fujishita, M. : Studies of adult T-cell leukemia Part II Anti-ATLA antibody in the families of ATL patients, Japan J. Cli. Hemat., 24 : 533-539, 1983. (in Japanese)

22) Tajima, K., Tominaga, S., Suchi, T., Kawagoe, T., Komoda, H., Hinuma, H., Oda, T. \& Fujita, K. : Epidemiological analysis of the disitribution of antibody to adult $\mathrm{T}$-cell leukemia-virus-associated antigen : Possible horizontal transmission on adult T-cell leukemia virus. Gann, $73: 893-901$, 1983.

23) Crosnier, J. : Hepatitis B in haemodialysis: Vaccination against HBs antigen. Proc EDTA, 18:231-240, 1981.

24) Osaki, K., Fukumoto, H., Morita, T., Otsuka, H., Maeda, E., Mitsueda, K., Kubozono, O., Yamaguchi, K., Harada, R., Otsuji, Y. \& Hashimoto, $\mathrm{S}$. : Immune responses to $\mathrm{HBs}$ vaccine in hemodialysis patients. J. Jpn. Soc. Dial. Ther., $16: 303-307,1983$. (In Japanese) 